\title{
MEKANISME GOOD CORPORATE GOVERNANCE TERHADAP MANAJEMEN LABA DAN KINERJA KEUANGAN
}

\author{
Miftah Muhammad Abduh \\ miftahmabduh@gmail.com \\ Ellen Rusliati \\ Fakultas Ekonomi dan Bisnis Universitas Pasundan
}

diterima: 31/10/2017; direvisi: 14/11/2017; diterbitkan: 31/8/2018

\begin{abstract}
This study aims to determine the influence of good corporate governance mechanism proxied with managerial ownership, institutional ownership, independent board of commissioners and audit committee, profit management condition as measured by discretionary accruals and financial performance as measured by return on assets mining company period 2012-2016. The sample are 11 companies. This research uses descriptive and verificative method using panel data regression analysis. The result shows that good corporate governance mechanism has significant effect to profit management at 53\%. Partially managerial ownership has no effect on earnings management while institutional ownership, independent board of commissioner have significant influence to earnings management. Good corporate governance mechanism has a significant effect on financial performance of $26 \%$, Partially managerial ownership, institutional ownership and independent board of commissioners have no effect on financial performance, while audit committee has an effect.
\end{abstract}

Keywords : good corporate governance mechanism; earning management; financial performance

\begin{abstract}
Abstrak
Penelitian ini bertujuan untuk mengetahui pengaruh mekanisme good corporate governance yang diproksikan dengan kepemilikan manajerial, kepemilikan institusional, dewan komisaris independen dan komite audit terhadap manajemen laba yang diukur dengan discretionary accruals dan kondisi kinerja keuangan yang diukur dengan return on assets pada perusahaan pertambangan periode 2012-2016. Sampel berjumlah 11 perusahaan. Penelitian menggunakan metode deskriptif dan verifikatif dengan analisis regresi data panel. Hasil penelitian menunjukkan bahwa mekanisme good corporate governance berpengaruh signifikan terhadap manajemen laba sebesar 53\%, secara parsial kepemilikan manajerial tidak berpengaruh terhadap manajemen laba sedangkan kepemilikan institusional, dewan komisaris independen dan komite audit berpengaruh signifikan terhadap manajemen laba. Mekanisme good corporate governance berpengaruh signifikan terhadap kinerja keuangan sebesar $26 \%$, secara parsial kepemilikan manajerial, kepemilikan institusional dan dewan komisaris independen tidak berpengaruh terhadap kinerja keuangan sedangkan komite audit berpengaruh.
\end{abstract}

Kata Kunci : mekanisme good corporate governance; manajemen laba; kinerja keuangan 


\section{PENDAHULUAN}

Perusahaan selalu dihadapkan pada kebutuhan dana dalam menjalankan kegiatan usahanya. Berbagai upaya dilakukan untuk memperoleh tambahan dana yang dapat berasal dari dalam maupun luar perusahaan. Semakin besar kegiatan operasi perusahaan, semakin besar pula dana yang dibutuhkan untuk menjalankannya, sehingga sumber dana yang berasal dari dalam tidak akan cukup untuk dapat menjalankan kegiatan operasi perusahaan. Perusahaan berusaha untuk mendapatkan dana yang berasal dari luar, seperti investor dan pemangku kepentingan (stakeholder) lainnya. Aspek yang menjadi perhatian para investor dan para stakeholder lainnya adalah kinerja keuangan perusahaan.

Pengukuran kinerja keuangan pada penelitian ini menggunakan Return on assets (ROA). Kondisi rata-rata ROA pada perusahaan sektor pertambangan periode 2012-2016 cenderung menurun. Pentingnya sumber pendanaan eksternal bagi perusahaan seringkali menuntut manajer memanipulasi laba untuk memperoleh keuntungan pribadi. Penelitian yang dilakukan Ratna (2013) menyimpulkan bahwa manajemen laba (earnings management) adalah perilaku manajemen untuk mengatur laba sesuai dengan keinginannya.

Kajian mengenai tindakan manajemen laba semakin meningkat dengan terbukanya skandal keuangan berskala besar. Contoh kasus manajemen laba yang terungkap oleh BAPEPAM-LK (Badan Pengawas Pasar Modal dan Lembaga Keungan di era tahun 2000-an diantaranya PT. Kimia Farma Tbk. dan PT. Indofarma Tbk. (Yulita, 2016). PT. Timah (persero) Tbk. pada laporan keuangan semester I tahun 2015 rugi sebesar Rp. 59 milyar, tetapi yang dilaporkan manajemen berhasil melakukan kegiatan efisiensi dan strategi yang tepat dan membuahkan kinerja positif. PT. Timah juga mencatatkan peningkatan utang, pada tahun 2013 utang sebesar Rp. 263 milyar dan pada tahun 2015 meningkat hingga Rp. 2,3 triliun (www. okezone.com/ diakses Juli 2017). PT. Garda Tujuh Buana Tbk. pada tahun 2012 mencatatkan penjualan sebesar Rp 1.148,05 milyar sedangkan harga pokok penjualan yang dikeluarkan sebesar Rp. 198,07 milyar atau $17 \%$ dari nilai penjualannya (www.neraca.co.id/ diakses Juli 2017).

Banyaknya praktek manajemen laba menuntut perusahaan menerapkan good corporate governance (tata kelola perusahaan yang baik) untuk meminimalisir bahkan mencegahnya. Mekanisme good corporate governance diproksikan dengan kepemilikan institusional, kepemilikan manajerial, dewan komisaris independen, serta komite audit. Yulita (2016) mengatakan kepemilikan manajerial dan kepemilikan instutisional dibentuk dengan tujuan mengatasi masalah keagenan (agency theory) dan diyakini dapat meminimalisir praktek manajemen laba. Penerapan mekanisme good corporate governance berguna untuk mengatur dan mengendalikan perusahaan sehingga tercipta nilai tambah (value added) untuk semua pemangku kepentingan, serta memberikan kemajuan terhadap kinerja (Tri, 2015).

Cadbury Commmittee of United Kingdom dalam Agoes dan Ardana (2013:101) menyatakan corporate governance mengatur hubungan antar stakeholders yang berkaitan dengan hak-hak dan kewajiban atau suatu sistem yang mengarahkan dan mengendalikan perusahaan. Kepemilikan manajerial akan mensejajarkan kepentingan manajemen dengan pemegang saham. Jensen dan Meckling dalam Asward (2015) berpendapat kepemilikan manajerial berhasil menjadi mekanisme untuk mengurangi masalah keagenan dari manajer dengan menyelaraskan kepentingan manajer dengan pemegang saham, manajemen laba sangat ditentukan oleh motivasi manajer.

Kepemilikan instutisional mendorong pengawasan terhadap kinerja manajemen. Asward (2015) mengatakan investor institusional merupakan investor yang berpengalaman, karena memfokuskan pada laba di masa datang. Menurut Suranta dalam Asward (2015), kepemilikan institusional berperan sebagai salah satu mekanisme good corporate governance dalam mengurangi tindakan manajemen laba. Komisaris independen merupakan merupakan pihak independen yang dibutuhkan untuk melakukan pengawasan terhadap kinerja manajemen. Menurut Asward (2015) semakin banyak jumlah anggota komisaris independen dalam perusahaan maka akan semakin baik tingkat pengawasan terhadap manajemen. Komite audit yang efektif diperlukan dalam pencapaian good corporate governance. Siallagan (2006) menyatakan adanya komite audit dalam perusahaan akan menekan manajemen laba, yang berarti kualitas laporan keuangan yang dihasilkan semakin tinggi. Penerapan good corporate governance dapat menghindarkan perusahaan dari praktek manajemen laba (Sriwedari, 2012; Pourali and Dadashi, 2014).

Jumlah saham yang dimiliki oleh manajer perusahaan mendorongnya untuk dapat meningkatkan kinerja perusahaan. Anggraini (2013) menyatakan bahwa kepemilikan manajerial yang semakin besar dalam perusahaan maka akan semakin produktif tindakan manajer dalam memaksimalkan kinerja perusahaan. Kepemilikan investor instutisional mendorong peningkatan pengawasan yang lebih optimal terhadap kinerja manajemen. Kepemilikan institusional meliputi perusahaan investasi, asuransi, bank, juga pemerintah yang menanamkan modalnya dalam perusahaan biasanya berupa saham dan ikut andil dalam pengambilan keputusan. Lestari (2015) mengatakan kinerja perusahaan dapat meningkat jika institusi mampu menjadi alat monitoring yang efektif, karena institusi tersebut akan selalu mengawasi kegiatan manajemen dalam menjalankan kegiatannya. 
Ardhiani dan Dian (2015) menyatakan keberadaan komisaris independen dan komite audit dalam perusahaan akan dapat mendorong manajemen bekerja dengan baik dan berpengaruh baik terhadap kinerja perusahaan. Perusahaan yang telah menerapkan good corporate governance berdampak baik bagi kinerja keuangan perusahaan. Menurut Sriwedari (2012) perusahaan yang telah menerapkan good corporate governance dapat membuat kinerja keuangan perusahaan yang baik. Jumlah saham yang dimiliki oleh manajemen perusahaan akan membuat manajer berusaha meningkatkan kinerja keuangannya. Saham yang dimiliki pihak institusi menjadi kontrol eksternal bagi internal perusahaan, sehingga kinerja perusahaan akan meningkat. Perusahaan yang memiliki anggota komisaris independen dalam perusahaan menjadikan kontrol internal bagi manajemen perusahaan untuk selalu berupaya meningkatkan kinerja perusahaan. Komite audit membantu dewan komisaris, untuk menjaga kualitas laporan keuangan perusahaan.

\section{METODE}

Metode yang digunakan yaitu metode deskriptif dan verifikatif menggunakan analisis regresi data panel. Operasionalisasi variabel ditunjukkan pada Tabel 1. Populasi adalah perusahaan sektor pertambangan yang terdaftar di Bursa Efek Indonesia tahun 2012-2016 dengan jumlah 39 (www.sahamoke.com). Teknik non probability sampling digunakan dengan kriteria : (1) Perusahaan sektor pertambangan periode 2012-2016 yang kontinu terdaftar di Bursa Efek Indonesia dan mempublikasikan laporan tahunan (www.idx.co.id), (2) Perusahaan sektor pertambangan periode 2012-2016 yang mempunyai informasi mengenai kepemilikan manajerial, kepemilikan instutisional, dewan komisaris independen dan komite audit. Sampel penelitian diperoleh 11 perusahaan.

\section{HASIL}

Hasil perhitungan statistik deskriptif terhadap 11 sampel perusahaan sektor pertambangan ditunjukkan pada Tabel 2.

Analisis regresi data panel adalah metode analisis yang menggabungkan data time series dengan data cross section. Langkah-langkahnya sebagai berikut: (1) Merumuskan ke dalam model analisis regresi data panel; model common effect, model fixed effect, dan model random effect, (2) Menentukan model analisis regresi data panel; uji chow, uji lagrange multiplier dan uji hausman. (3) Uji asumsi klasik; uji normalitas, heteroskedastisitas, multikolinearitas dan autokolerasi. (4) Pengujian hipotesis; hipotesis parsial dan simultan.

(5) Koefisien determinasi; parsial dan simultan.

Hasil uji Chow persamaan 1 dan 2 menunjukkan model yang terpilih adalah model fixed effect. Hasil uji Hausman persamaan 1 dan 2 menunjukkan model paling tepat untuk persamaan 1 adalah model random effect dan persamaan 2 adalah model fixed effect. Hasil uji asumsi klasik untuk kedua persamaan menunjukkan data berdistribusi normal, tidak terjadi multikolinieritas dan heteroskedastisitas, serta autokorelasi.

Hasil analisis regresi data panel persamaan 1 dan 2 ditunjukkan pada Tabel 3 dan 4.

Berdasarkan Tabel 3 diperoleh hasil kepemilikan manajerial, kepemilikan institusional, dewan komisaris independen, dan komite audit berpengaruh signifikan secara simultan terhadap manajemen laba pada perusahaan sektor pertambangan Periode 2012-2016. Nilai R- Square sebesar 0,5239, berarti mekanisme good corporate governance berpengaruh sebesar $52,39 \%$ terhadap manajemen laba dan sisanya $47,61 \%$ dipengaruhi oleh variabel lain yang tidak diteliti.

Berdasarkan Tabel 4 diperoleh hasil kepemilikan manajerial, kepemilikan institusional, dewan komisaris independen, dan komite audit berpengaruh signifikan secara simultan terhadap kinerja keuangan. Nilai koefisien determinasi berganda sebesar 0,6796 , berarti mekanisme good corporate governance berpengaruh sebesar 67,96\% terhadap kinerja keuangan pada perusahaan sektor pertambangan periode 2012-2016.

$$
\begin{aligned}
\mathrm{Y}= & 4,7913-0,009405 \mathrm{X}_{1}-0,013681 \mathrm{X}_{2}-0,091218 \mathrm{X}_{3} \\
& -0,314838 \mathrm{X}_{4}+\mathrm{e}
\end{aligned}
$$

Tabel 5 menunjukkan tidak ada pengaruh kepemilikan manajerial terhadap manajemen laba secara signifikan, sedangkan kepemilikan institusional, dewan komisaris, dan komite audit berpengaruh negatif signifikan terhadap manajemen laba pada perusahaan sektor pertambangan periode 2012-2016.

$$
\begin{aligned}
\mathrm{Y}= & 0,732595+0,628847 \mathrm{X}_{1}-0,025614 \mathrm{X}_{2}-0,278560 \mathrm{X}_{3} \\
& +3,734056 \mathrm{X}_{4}+\mathrm{e}
\end{aligned}
$$

Tabel 6 menunjukkan bahwa tidak terdapat pengaruh signifikan kepemilikan manajerial, kepemilikan institusional, dan dewan komisaris independen terhadap kinerja keuangan, sedangkan komite audit berpengaruh positif dan signifikan pada perusahaan sektor pertambangan periode 2012-2016.

\section{PEMBAHASAN}

Berdasarkan Tabel 2 diketahui bahwa kepemilikan manajerial diperoleh nilai mean sebesar 3,6778 berarti manajemen sebagai pemilik saham minoritas pada perusahaan sektor pertambangan karena persentase kepemilikan saham yang rendah, dengan nilai standar deviasi sebesar 6,3137. Berarti ada kesenjangan kepemilikan manajerial. Kepemilikan institusional rata-rata sebesar 59,5988 berarti pihak intitusi menjadi pemilik saham mayoritas pada perusahaan sektor 
pertambangan karena persentase kepemilikan saham yang cukup tinggi, dengan nilai standar deviasi sebesar 29,0173. Berarti tidak terdapat kesenjangan kepemilikan institusional.

Dewan komisaris independen diperoleh nilai mean sebesar 39,5541 yang berarti sudah sesuai dengan peraturan OJK Nomor 33/POJK 04/ 2014 yaitu minimal berjumlah $30 \%$, dengan nilai standar deviasi sebesar 9,3088. Berarti tidak terdapat kesenjangan dewan komisaris independen. Nilai rata-rata dari keseluruhan komite audit pada perusahaan pertambangan adalah 3,3818 anggota berarti sudah sesuai dengan pertaturan OJK Nomor 33/POJK 04/ 2015 yang minimal berjumlah 3 anggota, dengan nilai standar deviasi sebesar 0,8496. Berarti tidak terdapat kesenjangan komite audit.

Manajemen laba yang diukur dengan discretionary accruals diperoleh nilai mean sebesar 0,0007 artinya rata-rata perusahaan pertambangan cenderung tidak melakukan manajemen laba, karena nilai DA yang bernilai 0 (nol) menunjukkan tidak melakukkan praktek manajemen laba, dengan nilai standar deviasi sebesar 0,02. Berarti ada kesenjangan manajemen laba. Kinerja keuangan yang diukur dengan Return On Asstes diperoleh nilai mean sebesar 3,0249 yang artinya perusahaan pertambangan bisa menghasilkan laba dari aktiva yang dimilikinya sebesar 3,0249\%, dengan standar deviasi sebesar 6,9729. Berarti tingginya variasi kinerja keuangan.

Hasil analisis menunjukkan bahwa mekanisme good corporate governance dengan proksi kepemilikan manajerial, kepemilikan institusional, dewan komisaris independen, dan komite audit berpengaruh signifikan terhadap manajemen laba. Hal ini sesuai dengan pernyataan Watt dalam Sriwedari (2012), Pourali and Dadashi (2014); Patrick, et.al. (2015); Lady (2016); Yulita (2016) yang menyatakan bahwa cara yang digunakan untuk memonitor masalah kontrak dan membatasi perilaku opportunistic manajemen dalam hal ini manajemen laba adalah good corporate governance.

Kepemilikan manajerial secara parsial tidak berpengaruh terhadap manajemen laba, berarti jumlah saham yang dimiliki oleh manajemen dalam suatu perusahaan tidak mendorong tindakan manajemen laba. Rata-rata kepemilikan manajerial pada perusahaan sektor pertambangan rendah, menurut Jensen dan Meckling dalam Sriwedari (2012) menyebabkan rasa memiliki manajer atas perusahaan sebagai pemegang saham tidak cukup kuat dalam melakukan kecurangan pada laporan keuangan demi kepentingan pribadinya. Kepemilikan manajerial yang rendah artinya manajer pada perusahaan tidak mempunyai hak dan voting yang besar dalam proses pengambilan keputusan, hal inilah yang membuat manajemen tidak kuat dalam mengintervensi laporan keuangan, karena manajer menurut Jensen dan Meckling dalam Asward (2015) yang mengatakan bahwa manajemen laba sangat ditentukan oleh motivasi manajer itu sendiri. Hasil ini tidak sejalan dengan penelitian Lady (2016) dan Yulita (2016), namun sejalan dengan penelitian Sriwedari (2012) pada sampel perusahaan manufaktur.

Kepemilikan institusional berpengaruh terhadap manajemen laba, dengan koefisien -0.0137. Semakin tinggi saham yang dimiliki oleh pihak institusi dalam perusahaan, semakin rendah tindakan manajemen laba yang dilakukan manajer. Hasil penelitian ini sejalan dengan penelitian Lady (2016) dan Yulita (2016) menyatakan bahwa kepemilikan institusional berpengaruh signifikan terhadap manajemen laba, namun tidak sejalan dengan penelitian Pourali and Dadashi (2014).

Dewan komisaris independen berpengaruh negatif terhadap manajemen laba dengan koefisien -0,0912. Jensen dan Meckling dalam Sriwedari (2012) mengatakan komisaris independen merupakan posisi terbaik untuk melaksanakan fungsi monitoring agar terciptanya good corporate governance. Hasil penelitian ini sejalan dengan penelitian yang telah dilakukan oleh Patrick (2015) dan Luthans (2016).

Komite audit berpengaruh negatif terhadap manajemen laba dengan koefisien -0,3418. Komite audit yang efektif diperlukan dalam pencapaian good corporate governance. Hasil ini sejalan dengan pernyataan Xie, et.al.; Carcello, et.al. dalam Sriwedari (2012), Patrick, et.al. (2015), dan Luthan (2016).

Mekanisme good corporate governance berpengaruh terhadap kinerja keuangan, hal ini sesuai dengan pernyataan Jill et.al. dalam Riyanto (2011); Ardianto dan Dian (2015) menjelaskan bahwa corporate governance menjamin perusahaan akan melaksanakan kewajibannya kepada pihak yang berkepentingan (stakeholder) dengan tujuan mendatangkan maupun menjaga pemegang saham melalui kinerja keuangan.

Hasil analisis menunjukkan tidak adanya pengaruh kepemilikan manajerial terhadap kinerja keuangan. Hasil ini sesuai dengan pernyataan Tarigan dalam Setiyarini dan Lilik (2012) yang membuktikan bahwa rata-rata kinerja keuangan tanpa atau dengan adanya kepemilikan manajerial adalah sama. Kepemilikan manajerial yang rendah, menyebabkan rasa memiliki manajer atas perusahaan sebagai pemegang saham tidak cukup kuat dan tidak mampu memotivasi manajer untuk berusaha lebih giat dalam meningkatkan kinerja keuangan perusahaan. Hasil ini tidak sejalan dengan penelitian Intan dan Ida (2016) yang menyatakan bahwa kepemilikan manajerial berpengaruh signifikan terhadap manajemen laba, namun sejalan dengan penelitian Ardiani dan Dian (2015), serta Lestari (2015).

Kepemilikan institusional tidak berpengaruh terhadap kinerja keuangan, artinya kepemilikan institusional yang merupakan pengawas eksternal bagi perusahaan tidak efektif dalam upaya meningkatkan kinerja keuangan. Perusahaan sektor pertambangan yang dijadikan sampel memiliki kepemilikan institusional yang rendah sehingga kontrol eksternal terhadap 
perusahaan rendah dan tidak mampu mempengaruhi kinerja keuangan perusahaan tersebut. Hasil yang menunjukkan tidak adanya pengaruh disebabkan juga oleh data kinerja keuangan yang memiliki kesenjangan tinggi terutama terjadi pada tahun 2014 dan 2015, dimana kinerja keuangan rata-rata perusahaan pertambangan yang menurun akibat adanya krisis global yang membuat harga batubara dunia turun sehingga mempengaruhi pendapatan bagi perusahaan (www. detik.com). Hasil ini tidak sejalan dengan penelitian Ardiani dan Dian (2015), Lestari (2015), namun sejalan dengan penelitian yang dilakukan oleh Putra (2013), Wiranata dan Nugrahanti (2013), dan Meiryani (2015).

Dewan komisaris independen ternyata tidak berpengaruh terhadap kinerja keuangan menunjukkan tugas mengawasi kegiatan manajemen tidak efektif dalam upaya meningkatkan kinerja keuangan. Hal ini dapat disebabkan banyaknya dewan komisaris independen yang merangkap menjadi dewan komisaris dan direksi perusahaan lain, dan tingginya kesenjangan kinerja keuangan terutama tahun 2014 dan 2015, dimana kinerja keuangan rata-rata perusahaan pertambangan yang menurun akibat adanya krisis global yang membuat harga batubara dunia turun (www.detik.com). Hasil ini tidak sejalan dengan penelitian Paul (2015), namun sejalan dengan Adestian (2016).

Komite audit berpengaruh positif terhadap kinerja keuangan. Riyanto (2011) menyatakan keberadaan komite audit diterima sebagai suatu bagian dari organisasi perusahaan yang dapat mengakibatkan kinerja keuangan mengalami peningkatan. Hasil penelitian ini sejalan dengan penelitian Paul (2015).

\section{KESIMPULAN}

Kondisi mekanisme good corporate governance dengan proksi kepemilikan manajerial mengalami cenderung menurun dengan nilai rata-rata sebesar 3,68\%. Kepemilikan institusional cenderung menurun dengan nilai rata-rata 59,60\%. Dewan Komisaris Independen berfluktuasi dengan nilai rata-rata $39,55 \%$. Komite audit mengalami cenderung menurun dengan nilai rata-rata $3,38 \%$. Kondisi manajemen laba yang diukur dengan discretionary accruals cenderung meningkat dengan nilai rata-rata $-0,709$. Kondisi kinerja keuangan yang diukur dengan Return on assets cenderung menurun dengan nilai rata-rata 3,025\%.

Mekanisme good corporate governance berpengaruh signifikan terhadap manajemen laba sebesar 52,39\%. Secara parsial kepemilikan manajerial tidak berpengaruh signifikan, sedangkan kepemilikan intitusional, dewan komisaris independen, dan komite audit berpengaruh signifikan terhadap manajemen laba. Mekanisme good corporate governance berpengaruh signifikan terhadap kinerja keuangan sebesar $67,96 \%$. Secara parsial kepemilikan manajerial, kepemilikan institusional, dan dewan komisaris independen tidak berpengaruh signifikan, sedangkan komite audit berpengaruh signifikan terhadap kinerja keuangan.

\section{DAFTAR PUSTAKA}

Adestian, Yuda. 2016. Pengaruh Dewan Komisaris, Dewan Direksi, Dewan Komisaris Independen, Komite Audit dan Ukuran Perusahaan pada Kinerja Perusahaan Perbankan yang Listing di BEI tahun 2012-2014. Jurnal Akuntasi dan Keuangan. Vol. 2 No. 5. www.jurnal.dinus.ac.id

Agoes, Sukrisno, dan I Cenik Ardana. 2013. Auditing Petunjuk Praktis Pemeriksaan Akuntan oleh Akuntan Publik (Edisi 4). Jakarta: Salemba Empat. Anggraeni, Riske Meitha. 2013 Pengaruh Struktur Kepemilikan Manajerial, Ukuran Perusahaan, dan Praktik Corporate Governance terhadap Manajemen Laba. Studi Empiris pada perusahaan Manufaktur yang Terdaftar di BEI Tahun 2009 2011. eprints.undip.ac.id.

Ardiani dan Dian. 2015. Peningkatan Kinerja Keuangan memalui Mekanisme Good corporate governance. Management Dynamics Conference (MADIC). www.jurnal.unnes.ac.id

Asward, Ismalia. 2015. Pengaruh Mekanisme Good corporate governance terhadap Manajemen Laba dengan Pendekatan Conditional Revenue Model. Jurnal Manajemen Teknologi. Vol. 4 No. 1. http:// dx.doi.org/10.12695/jmt/2014.14.1.2.

Fahmi Irham. 2013. Analisis Laporan Keuangan. Bandung: Alfabeta.

Intan dan Ida. 2016. Pengaruh Kepemilikan Manajerial, Kepemilikan Institusional, Dewan Komisaris Independen terhadap Return on assets. Jurnal Riset Mahasiswa Akuntansi. Vol. 5. No. 5. http://ejournal. unud.ac.id.

Kasmir. 2012. Analisis Laporan Keuangan. Bandung. Jakarta. PT. Raja Grafindo Perkasa.

Lady P, Fernanda. 2016. Analisis Mekanisme Good corporate governance terhadap Manajemen Laba pada Perusahaan Manufaktur yang Terdaftar di BEI. Jurnal Riset Mahasiswa Akuntansi. Vol. 4. No.4. http://ejournal.unikama.ac.id.

Lestari, Yuni Tri. 2015. Pengaruh Corporate Governance terhadap Kinerja Keuangan: Corporate Sosial Responsibility sebagai Variabel Intervening. Jurnal Ilmu dan Riset Akuntansi. Vol. 4 No. 7. http:// ejournal.stiesia.ac.id.

Luthan, Elvira; Ileh Satria; Ilmainir. 2016. The Effect of Good corporate governance Mechanism to Earnings management Before and After IFRS Convergence. Procedia Social and Behavioral Sciences 219 (2016) 465 - 471. www.sciencedirect.com.

Meiryani. 2015. Mechanism of Good corporate governance, earnings management on Financial Performance in Banks Listed in Indonesia Stock Exchange Using Path Analysis. Australian Journal 
of Basic and Applied Sciences, 9 (23) July, Pages: $573-584$.

Peraturan Otoritas Jasa Keuangan Nomor 33/ Pojk.04/2014 (www.google.com)

Peraturan Otoritas Jasa Keuangan Nomor 33/ Pojk.04/2015 (www.google.com)

Patrick, Egbunike Amaechi; Ezelibe Chizoba Paulinus; Aroh Nkechi Nympha. 2015. The Influence of Corporate Governance on Earnings management Practices: A Study of Some Selected Quoted Companies in Nigeria. American Journal of Economics. Vol. 1 No. 5. www.aiscience.com.

Paul, Gadi Dung. 2015. Impact of Corporate Governance on Financial Perfomance of Microfinance Banks in North Central Nigeria. International Journal of Humanities Social Science and Education. Vol. 2 No. 1. www.arcjournal.org.

Pourali, Mohammad Reza and Nasrin Dadashi. 2014. The Relationship Between Corporate Governance Mechanisms and Profit Smoothing. Technical Gazette 21, 3 (2014), 614-621.

Putra, Andhika Surya. 2013. Analisis Pengaruh Ukuran Perusahaan, Kepemilikan Institusional dan Kepemilikan Manajerial terhadap Kinerja Keuangan dan Dampaknya terhadap Nilai Perusahaan. Jurnal Ekonomi da Bisnis. Vol. No. 2. www.enprints. ums.ac.id

Ratna S, Septiana. 2013. Pengaruh Leverage dan Mekanisme Good corporate governance terhadap Manajemen Laba. Jurnal Ilmu dan Riset Akuntansi. Vol. 2 No. 6. http://ejournal.stiesia.ac.id.

Riyanto, Ardian Ganang. 2011. Analisis Pengaruh Mekanisme Good corporate governance dan Privatisasi terhadap Kinerja Keuangan. Studi pada BUMN yang Tercatat di Bursa Efek Indonesia periode privatisasi 2001 - 2006. eprints.undip.ac.id Setiyarini dan Lilik Purwanti. 2011. Mekanisme Good corporate governance, Manajemen Laba dan Kinerja Perusahaan. Studi Empiris Pada Perusahaan Yang Terdaftar di BEI. Universitas Brawijaya. download.portalgaruda.org/article.

Siallagan, Hamonangan dan Mas'ud Machfoedz. 2006. Mekanisme Corporate Governance, Kualitas Laba, dan Nilai Perusahaan. Simposium Nasional Akuntasni 9 Padang. https://smartaccounting.files. wordpress.com.

Sriwedari, Tuti. 2012. Mekanisme Good corporate governance, Manajemen Laba dan Kinerja Keuangan Perusahaan Manufaktur di Bursa Efek Indonesia. Jurnal Mediasi. Vol. 4 No. 1. http:// digilib.unimed.ac.id.

Sulistyanto, Sri. 2008. Manajemen Laba Teori dan Model Empiris. Jakarta: PT Raja Grasindo Persada. Wiranata, Yullius Ardy dan Yeterina Widi Nugrahanti. 2013. Pengaruh Struktur Kepemilikan terhadap Profitabilitas pada Perusahaan Manufaktur. Vol. 15 No. 1. Jurnal Akuntansi dan Keuangan, Vol. 15, No.1, Mei, 15 - 26. www.jurnalakuntansi.petra. ac.id.

www.detik.com/ di akses Mei 2017

www.idx.co.id/ di akses Mei 2017

www.neraca.co.id/ di akses Juli 2017

www.okezone.com/ diakses Juli 2017

www.sahamoke.com

Yulita A, Selvy. 2016. Pengaruh Good corporate governance pada Manajemen Laba (Studi Empiris pada Perusahaan Manufaktur yang Terdaftar di Bursa Efek Indonesia Tahun 2013-2014). Jurnal Riset Mahasiswa Akuntansi. Vol. 4 No. 3. http:// ejournal.unikama.ac.id.

\section{LAMPIRAN}

Tabel 2. Statistik Deskriptif

\begin{tabular}{lrrrrrr}
\hline & $\begin{array}{c}\text { Kinerja } \\
\text { Keuangan (ROA) }\end{array}$ & $\begin{array}{c}\text { Manajemen } \\
\text { Laba (DA) }\end{array}$ & $\begin{array}{c}\text { Kepemilikan } \\
\text { Manajerial }\end{array}$ & $\begin{array}{c}\text { Kepemilikan } \\
\text { Institusional }\end{array}$ & $\begin{array}{c}\text { Dewan Komisaris } \\
\text { Independen }\end{array}$ & Komite Audit \\
\hline Mean & 3,024909 & 0.000718 & 3,677869 & 59,59880 & 39,55411 & 3,381818 \\
Median & 2,860000 & 0.000270 & 0,016226 & 59,09091 & 33,33333 & 3,000000 \\
Maximum & 22,86000 & 0.116190 & 21,74473 & 98,73230 & 66,66667 & 7,000000 \\
Minimum & $-16,27000$ & -0.076550 & $3,40 \mathrm{E}-05$ & 10,68035 & 25,00000 & 2,000000 \\
Std. Dev. & 6,972975 & 0.027462 & 6,313778 & 29,01737 & 9,308868 & 0,849638 \\
Observations & 55 & 55 & 55 & 55 & 55 & 55 \\
\hline
\end{tabular}

Sumber: Data sekunder yang diolah dengan Eviews 9 
Tabel 3. Uji F dan Koefisien Determinasi Simultan Persamaan 1: Pengaruh Mekanisme Good corporate governance terhadap Manajemen Laba

\begin{tabular}{llll}
\hline \multicolumn{4}{l}{ Weighted Statistics } \\
\hline R-squared & 0.523907 & Mean dependent var & -0.172330 \\
Adjusted R-squared & 0.485819 & S.D. dependent var & 0.617496 \\
S.E. of regression & 0.442784 & Sum squared resid & 9.802902 \\
F-statistic & 13.75536 & Durbin-Watson stat & 1.608408 \\
Prob(F-statistic) & 0.000000 & & \\
\hline
\end{tabular}

Sumber: Olahan data Eviews 9
Tabel 4. Uji F dan Koefisien Determinasi Simultan Persamaan 2: Pengaruh Mekanisme Good corporate governance terhadap Kinerja Keuangan

\begin{tabular}{lcll}
\hline Cross-section fixed (dummy variables) & \\
\hline R-squared & 0.679693 & Mean dependent var & 3.024909 \\
Adjusted R-squared & 0.567586 & S.D. dependent var & 6.972975 \\
S.E. of regression & 4.585304 & Akaike info criterion & 6.110591 \\
Sum squared resid & 841.0006 & Schwarz criterion & 6.658045 \\
Log likelihood & -153.0412 & Hannan-Quinn criter. & 6.322296 \\
F-statistic & 6.062872 & Durbin-Watson stat & 1.421863 \\
Prob(F-statistic) & 0.000003 & & \\
\hline Sumber: Olahan data Eviews 9 & &
\end{tabular}

Tabel 5. Model Regresi Data Panel dan Uji t (Parsial)

Persamaan 1: Pengaruh Mekanisme Good corporate governance terhadap

Manajemen Laba

Dependent Variable: Manajemen Laba (DA)

Method: Panel EGLS (Cross-section random effects)

Periods included: 5

Cross-sections included: 11

Total panel (balanced) observations: 55

\begin{tabular}{lllll}
\hline \multicolumn{1}{c}{ Variable } & Coefficient & Std. Error & t-Statistic & Prob. \\
\hline C & 4.791327 & 0.759695 & 6.306912 & 0.0000 \\
Kepemilikan Manajerial & -0.009405 & 0.033168 & -0.283568 & 0.7779 \\
Kepemilikan Institusional & -0.013681 & 0.006278 & -2.179035 & 0.0341 \\
Dewan Komisaris Independen & -0.091218 & 0.012779 & -7.138115 & 0.0000 \\
Komite Audit & -0.314838 & 0.130773 & -2.407512 & 0.0198 \\
\hline
\end{tabular}

Sumber: Olah data Eviews 9

Tabel 6. Model Regresi Data Panel dan Uji Parsial

Persamaan 2: Pengaruh Mekanisme Good corporate governance terhadap Kinerja Keuangan

Dependent Variable: Kinerja Keuangan (ROA)

Method: Panel Least Squares

Sample: 20122016

Periods included: 5

Cross-sections included: 11

Total panel (balanced) observations: 55

\begin{tabular}{lllll}
\hline \multicolumn{1}{c}{ Variable } & Coefficient & Std. Error & t-Statistic & Prob. \\
\hline Kepemilikan Manajerial & 0.628847 & 1.089611 & 0.577130 & 0.5671 \\
Kepemilikan Institusional & -0.025614 & 0.052207 & -0.490624 & 0.6264 \\
Dewan Komisaris Independen & -0.278560 & 0.164602 & -1.692321 & 0.0984 \\
Komite Audit & 3.734056 & 1.433195 & 2.605408 & 0.0128 \\
C & 0.732595 & 8.985867 & 0.081527 & 0.9354 \\
\hline
\end{tabular}

Sumber: Olah data Eviews 9 
Tabel 1. Operasionalisasi Variabel

\begin{tabular}{|c|c|c|c|c|}
\hline Variabel & Definisi Variabel & Indikator & Pengukuran & Skala \\
\hline $\begin{array}{l}\text { Kepemilikan } \\
\text { Manajerial } \\
\quad\left(\mathrm{X}_{1}\right)\end{array}$ & $\begin{array}{l}\text { Jumlah kepemilikan saham oleh pihak } \\
\text { manajemen dari seluruh modal saham } \\
\text { perusahaan. } \\
\text { Ardiani dan Dian (2015) }\end{array}$ & $\begin{array}{l}\text { - Jumlah saham } \\
\text { yang dimiliki oleh } \\
\text { manajemen } \\
\text { - Jumlah saham yang } \\
\text { beredar }\end{array}$ & $\begin{array}{c}\frac{\Sigma \text { Saham Manajemen }}{\Sigma \text { Saham Beredar }} \times 100 \% \\
\text { Ardiani dan Dian (2015) }\end{array}$ & Rasio \\
\hline $\begin{array}{l}\text { Kepemilikan } \\
\text { Institusional } \\
\quad\left(\mathrm{X}_{2}\right)\end{array}$ & $\begin{array}{l}\text { Kepemilikan Institusional adalah } \\
\text { jumlah kepemilikan saham perusahaan } \\
\text { oleh pihak institusi, seperti perbankan, } \\
\text { perusahaan asuransi, dana pensiun, } \\
\text { reksadana dan institusi lain. } \\
\text { Ardiani dan Dian (2015) }\end{array}$ & $\begin{array}{l}\text { - Jumlah saham yang } \\
\text { dimiliki oleh pihak } \\
\text { institusi. } \\
\text { - Jumlah saham yang } \\
\text { beredar. }\end{array}$ & $\begin{array}{c}\frac{\Sigma \text { Saham Institusional }}{\Sigma \text { Saham Beredar }} \times 100 \% \\
\text { Ardiani dan Dian }(2015)\end{array}$ & Rasio \\
\hline $\begin{array}{l}\text { Dewan } \\
\text { Komisaris } \\
\text { Independen } \\
\left(\mathrm{X}_{3}\right)\end{array}$ & $\begin{array}{l}\text { Anggota dewan komisaris yang dari luar } \\
\text { pemegang saham perusahaan. } \\
\text { Ardiani dan Dian }(2015)\end{array}$ & $\begin{array}{l}\text { - Jumlah dewan } \\
\text { komisaris independen. } \\
\text { - Jumlah dewan } \\
\text { komisaris. }\end{array}$ & $\begin{array}{c}\frac{\Sigma \text { Komisaris Independen }}{\Sigma \text { Dewan Komisaris }} \times 100 \% \\
\text { Ardiani dan Dian (2015) }\end{array}$ & Rasio \\
\hline $\begin{array}{l}\text { Komite } \\
\text { Audit } \\
\left(\mathrm{X}_{4}\right)\end{array}$ & $\begin{array}{l}\text { Sekelompok orang yang ditunjuk dewan } \\
\text { komisaris yang bertanggungjawab } \\
\text { untuk membantu auditor dalam } \\
\text { mempertahankan independensi pihak } \\
\text { manajemen. } \\
\text { Ardiani dan Dian ( } 2015\end{array}$ & $\begin{array}{l}\text { - Jumlah anggota komite } \\
\text { audit di perusahaan. }\end{array}$ & ¿ Anggota Komite Audit & Rasio \\
\hline $\begin{array}{l}\text { Manajemen } \\
\text { Laba } \\
\left(\mathrm{Y}_{1}\right)\end{array}$ & $\begin{array}{l}\text { Perilaku oportunis manajer untuk } \\
\text { mempermainkan angka-angka dalam } \\
\text { laporan keuangan sesuai dengan tujuan } \\
\text { yang akan dicapai. } \\
\text { Dechow et.al dalam Sri Sulistyanto } \\
(2008: 4)\end{array}$ & $\begin{array}{l}\text { - Menghitung Total } \\
\text { Akrual (TA). } \\
\text { - Menghitung Non } \\
\text { Discretionary accruals } \\
\text { (NDA). } \\
\text { - Menghitung } \\
\text { Discretionary accruals } \\
\text { (DA). }\end{array}$ & $\begin{array}{l}\text { - Langkah Pertama } \\
\qquad \mathrm{TA}_{\mathrm{it}}=\mathrm{NI}_{\mathrm{it}} \mathrm{CFO}_{\mathrm{it}} \\
\text { - Langkah Kedua } \\
\mathrm{NDA}_{\mathrm{t}} / \mathrm{A}_{\mathrm{it}-1}=\beta_{1}\left(1 / \mathrm{A}_{\mathrm{it}-1}\right)+\beta_{2}\left(\left(\Delta \mathrm{REV}_{\mathrm{t}^{-}}\right.\right. \\
\left.\qquad \mathrm{REC}_{\mathrm{t}} / \mathrm{A}_{\mathrm{it}-1}\right)+\beta_{3}\left(\Delta \mathrm{PPE}_{\mathrm{t}} / \mathrm{A}_{\mathrm{it}-1}\right) \\
\text { - Langkah Ketiga } \\
\quad \mathrm{DA}_{\mathrm{it}}=\left(\mathrm{TA}_{\mathrm{it}} / \mathrm{A}_{\mathrm{it}}\right)-\mathrm{NDA}_{\mathrm{it}} \\
\text { Dechow et.al dalam Sri Sulistyanto } \\
\text { (2008:4) }\end{array}$ & Rasio \\
\hline $\begin{array}{l}\text { Kinerja } \\
\text { Keuangan } \\
\quad\left(\mathrm{Y}_{2}\right)\end{array}$ & $\begin{array}{l}\text { Kinerja Keuangan yang diukur dengan } \\
\text { Return On Asset (ROA) adalah rasio } \\
\text { yang digunakan untuk mengukur } \\
\text { kemampuan perusahaan dalam } \\
\text { memperoleh keuntungan berdasarkan } \\
\text { tingkat aset yang tertentu. } \\
\text { Kasmir (2012:201) }\end{array}$ & $\begin{array}{l}\text { - Total laba bersih } \\
\text { - Total Aset }\end{array}$ & $\begin{array}{l}\text { Total Laba Bersih } \\
\text { Total Asset } \\
\text { Kasmir (2012:201) }\end{array}$ & Rasio \\
\hline
\end{tabular}

